\title{
A Proposed Conceptual Model of Relevance of Teacher Education Curriculum
}

\author{
Michael Bobias Cahapay ${ }^{1 *}$ (1)
}

${ }^{1}$ College of Education, Mindanao State University, General Santos City, PHILIPPINES

*Corresponding Author: mbcahapay@up.edu.ph

Citation: Cahapay, M. B. (2021). A Proposed Conceptual Model of Relevance of Teacher Education Curriculum. International Journal of Pedagogical Development and Lifelong Learning, 3(1), ep2105. https://doi.org/10.30935/ijpdll/10880

\begin{abstract}
There is a paucity of research and unresolved debate on the criterion of relevance in curriculum development across educational contexts. This paper is an initial research with the goal to propose a conceptual model of relevance in the context of teacher education. Following a qualitative research design, this study involved a maximum variation sampled participants from different sectors of teacher education. The main data analysis technique used was the thematic analysis. The result illustrates relevance through three themes; personal relevance, professional relevance, and societal relevance. This paper demonstrates relevance in the context of teacher education as a multifaceted criterion and can be presented through three expanding levels. A conceptual model of the relevance of the teacher education curriculum is depicted in the discussion of this study. Acknowledging further the robust process of model development in curriculum studies, continuous validation of the proposed model is recommended.
\end{abstract}

Keywords: relevance, conceptual model, teacher education, curriculum studies

Received: 29 Aug. $2020 \bullet$ Accepted: 5 Dec. 2020

\section{INTRODUCTION}

The emphasis on the criterion of relevance has been continuously considered in educational discourses in recent years due to the many changes. These changes direct a significant pressure on curriculum development to fundamentally consider the criterion of relevance in the curriculum development. However, there is no single narrative of a criterion of relevance in curriculum development as such a criterion evolves through conditions, places, and times.

Teacher education students undeniably play crucial roles in the future of the educational systems. This cannot be attained without a relevant teacher education curriculum that will prepare them for this huge task. This implies that the curriculum that needs to be offered to them during preservice education must be relevant to what they are expected when they assume roles in the field (Mahmood, 2001; Mungure, 2016). Thus, curriculum developers should carefully construct a teacher education curriculum that is anchored on the criterion of relevance.

The Philippine Commission on Higher Education Memorandum Order No. 2 Series of 2011 made the formulation of curricular programs in higher education minimally prescriptive. This allowed institutions of higher learning in the country to enjoy the freedom of determining their curriculum to make it relevant to their needs. This mandate addresses the need for teacher education institutions in the southern Philippines to develop a relevant curriculum considering the unique cultural, social, political, and financial context of their immediate communities. This condition calls for a need to operationally define the criterion of relevance if the goal is to develop a relevant curriculum for teacher education in the region.

The United Nations Educational, Scientific, and Cultural Organization (UNESCO, 2020) calls for relevance in the context of education as the applicability of a curriculum to the needs, interests, desires, and prospects of students and the community as a whole. The criterion of relevance, however, is a multifaceted discussion. There are several interpretations and even arguments that appear considering its different aspects (Robins, 1974; Skinner, 1978; Levitt, 2002; Stuckey, 2013; Hartwell, 2014). It has been also explored in whole or in part particularly across the different fields and aspects of education (e.g. see Carver, 1990; Cheplogoi, 2016; Dirin \& Nieminen, 2016; Hartwell, 2014; Hiim, 2017; Janssen-Brandt et al., 2017; Johnson et al., 2017; Kotkas et al., 2016; Lewis, 2002; Lombard, 1999; Mumbo \& Kinaro, 2015; Mungure, 2016; Pengestu, 2019; Rao \& Wedajo, 2018; Roofe, 2020; Stroupe, 2003).

Furthermore, one empirical research conducted by Robins (1974) indicates that relevance as a concept received overwhelming attention and there was wide disagreement about its meaning in higher education and the effective ways of achieving it. Due to the scarcity of studies and the continuing disagreements on relevance especially in the context of teacher education and curriculum development, it is timely to research on it.

This study is primarily significant to the people involved in the curriculum development in teacher education in the regional context. 
The results may present evidence that will serve as a guide in planning and evaluating the relevance of a teacher education curriculum. Furthermore, this study is important to scholars interested in examining the nuances that surround the criterion of relevance. The results may increase knowledge about relevance as defined in a particular context.

Thus, as an initial step, this study aimed to propose a conceptual model of the relevance of the teacher education curriculum. Specifically, it answered the following questions:

1. What is a relevant teacher education curriculum according to the stakeholders?

2. What conceptual model of relevance of teacher education curriculum can be proposed?

\section{METHODS}

\section{Research Design}

This study primarily employed a qualitative research design to develop a conceptual model of relevance. Creswell (2013) notes that qualitative research design typically aids in researching topics where little is known about a phenomenon. This suggests that qualitative research design is not focused on the testing of a hypothesis, but on the description, examination, and interpretation of a given unexplored phenomenon. This research design suits the problem of this study involving the criterion of relevance.

However, Husbands, Jowett, Barton, and Coast (2017) observe that the application of qualitative research design to inform model development has been largely unrecorded though extensively applied in many fields of research. They explained that although methods of model development are traditionally and usually quantitative, some scholars have suggested that qualitative approaches can offer appropriate and robust practices for aspects of model development.

A closer look at related researches in curriculum studies using qualitative research design to inform model development (e.g. Milenski, 1973; Norman, 2018; Wallace, 1999) has demonstrated how typical qualitative techniques such as document reviews, observations, focus groups, and interviews can be well applied to explore existing methods, guide practice, and contribute to the structural development of curriculum models. These studies contribute to the growing demand for the use of qualitative approaches in developing models in curriculum studies.

\section{Study Participants}

The criterion of relevance has been traditionally described through the lens of different stakeholders (e.g. Robins, 1974; Skinner, 1978). Thus, situated in the field of teacher education, the participants of this study were selected through maximum variation sampling, a technique used to select representative of participants who can offer a wide range of information of central importance to the purpose of the research (Patton, 1987).

Specifically, the sample of participants in this study consisted of two university administrators, two education professors, two education students, two education program specialists, two basic education principals, and four basic education teachers. They are considered to represent the context of teacher education in the region, thus provide information about what constitutes a relevant teacher education curriculum.

\section{Data Source}

A technique employed to qualitatively uncover the latent description of relevance in the context of teacher education in this study is the interview. A structured interview is seen to be appropriate because the questions are formulated in advance (Denzin \& Lincoln, 2017) based on the defined purpose of this study. Aside from the personal interview, a form of online interview was also conducted due to geographical constraints.

Furthermore, the researcher used an interview guide to keep focused on the interest of this study. It contained open-ended questions designed to generate information regarding a relevant teacher education curriculum. The validation of the tool was conducted to three experts in teacher education for content evaluation of the questions.

\section{Analysis Technique}

The utterances recorded from interviews were subjected to thematic analysis. This technique employs analysis of utterances, interpreting them into constructs and concepts; then grouping related content into themes, simplifying the results, and at the same time structuring the data to answer the research question (Moore \& McCabe, 2005).

Three stages of thematic analysis were performed in this study. First, from the transcribed interview of the participants, the researcher coded utterances relevant to the interest of this study. These units were organized into several constructs. Second, the researcher identified similarities and differences among the constructs. This step served as a basis for the categorization of the constructs into broader units called concepts. Third, a comparison was performed to determine meaningful patterns among the concepts. After a repetitive process of analysis, the concepts were then cataloged into overarching units known as themes.

\section{RESULTS}

This study primarily looked into the meaning of relevance in the context of teacher education. The resulting themes that emerge from the interviews are presented in Table 1.

As shown in Table 1, the analysis of constructs and concepts produced the themes of relevance in teacher education.

Personal relevance. As a blueprint that guides the educational process, the intended teacher education curriculum as expressed by the education stakeholders should demonstrate its relevance through the development of competencies of prospective teachers at the very basic point, the personal level. This relevance at the personal level consists of lifelong learning, values development, and financial literacy.

The personal aspect of relevance expected to be demonstrated by the teacher education curriculum is specifically expressed by the participants. For example, focusing on the development of the values, one participant explained that:

"What must be covered is, I think, the values education since it is not explicitly part of the curriculum. That is why based on the result of my study on employers satisfaction, there are many teachers who have impressive performance but values is the problem. It ranks the lowest in the result" (Participant 12). 
Table 1. Thematic analysis of relevance in teacher education

\begin{tabular}{|c|c|c|}
\hline Construct & Concept & Theme \\
\hline - Prepare for life through education because education is life itself & \multirow[t]{3}{*}{ Lifelong learning } & \multirow[t]{7}{*}{ Personal relevance } \\
\hline - Have lifelong skills that will help one to survive the real world. & & \\
\hline - Find modern access to knowledge independently & & \\
\hline - Possess the right attitude as part of living with others & \multirow[t]{2}{*}{ - Values development } & \\
\hline - Develop values aside from the different competencies in teaching & & \\
\hline - Demonstrate competencies related to financial management & \multirow[t]{2}{*}{ Financial literacy } & \\
\hline - Possess the literacy related to handling finances & & \\
\hline - Plan instruction with consideration of the congruence of all elements & \multirow{4}{*}{$\begin{array}{l}\text { Appropriate instructional } \\
\text { planning }\end{array}$} & \multirow[t]{17}{*}{ Professional relevance } \\
\hline - Design instruction that covers all aspects of the learners & & \\
\hline - Design instructional materials appropriate to the target learners & & \\
\hline - $\quad$ Select appropriate developmentally appropriate teaching strategies & & \\
\hline - Deliver instruction orally in an effective manner & \multirow{3}{*}{$\begin{array}{l}\text { Effective instructional } \\
\text { implementation }\end{array}$} & \\
\hline - Employ interactive teaching strategies successfully in actual teaching & & \\
\hline - Use positive discipline to manage difficult behaviors of learners in the class & & \\
\hline - $\quad$ Carry out assessment strategies depending on grade level and subject area & \multirow{2}{*}{$\begin{array}{l}\text { Developmental instructional } \\
\text { evaluation }\end{array}$} & \\
\hline - Provide constant constructive feedback for the growth of learners & & \\
\hline - Conduct research to study background information of learners & \multirow[t]{3}{*}{ Reflective teaching practice } & \\
\hline - Have research-based knowledge about learning to know the situation & & \\
\hline - Evaluate the outcome of teaching and learning situations & & \\
\hline - Be literate with all technological aspects that can be applied to teaching & \multirow{3}{*}{$\begin{array}{l}\text { Information technology } \\
\text { integration }\end{array}$} & \\
\hline - Use available technology as an essential tool for teaching and learning & & \\
\hline - Use information and communication technology in implementing instruction & & \\
\hline - Master knowledge on the content of the field of specialization & \multirow[t]{2}{*}{ Content knowledge mastery } & \\
\hline - Possess competencies are related to mastery of the content & & \\
\hline - Cover the teaching of the fundamentals of peace education & \multirow[t]{2}{*}{ Peace education } & \multirow[t]{8}{*}{ Societal relevance } \\
\hline - $\quad$ Mandated to teach peace education to the students & & \\
\hline - Do research that identifies the needs of the community & Community research & \\
\hline - Demonstrate awareness on environmental issues such as climate change and disaster reduction & Ecological literacy & \\
\hline - Demonstrate competencies of leadership, citizenship, and global awareness & \multirow[t]{2}{*}{ Global citizenship } & \\
\hline - Demonstrate awareness on social issues such as violent extremism and radicalization & & \\
\hline - Get to know the diversity and context of the community & \multirow[t]{2}{*}{ Multicultural literacy } & \\
\hline Demonstrate a passion to educate people from different cultures & & \\
\hline
\end{tabular}

Another aspect of personal relevance that repetitively appeared is the lifelong learning. A participant

"New knowledge is being generated every day; what is true today may not be true tomorrow. The curriculum, to be relevant at all times, must equip prospective teachers with skills to become independent learners the moment they graduate, so that, when they eventually work in the field, whatever new knowledge will confront them, they will have the ability to learn anew" (Participant 05).

Professional relevance. The education stakeholders further articulated that an intended teacher education curriculum should further ensure the development of the future teachers in terms of professionally relevant competencies related to appropriate instructional planning, effective instructional implementation, developmental instructional evaluation, reflective teaching practice, information technology integration, and content knowledge mastery.

This concept of professional relevance is articulated in different ways by the participants but they all boil down to common elements. Based on her experience as a classroom teacher in the field, one participant seemed to capture these elements of professional relevance:

"Among the teacher competencies that are relevant include mastery of the topic; alignment of lesson plan from objectives down to evaluation; the use and integration of technology in delivering lessons; the use of appropriate and interactive teaching strategies in teaching and learning lessons; providing constant constructive feedback for students growth; and the conduct of different assessments that measure content knowledge and content performance" (Participant 02).

These elements of professional relevance are parallel to the ideas of another participant. As a supervisor providing technical assistance for the continuous development of teachers in the field, he agreed that:

\begin{abstract}
"First, the curriculum should equip students with mastery of knowledge on the content of their level of specialization... Second, the curriculum should provide them adequate knowledge on the curriculum, which covers the learning and performance standards, competencies and varied assessment strategies per grade level and subject area... Third, the curriculum should provide them pedagogical knowledge and skills particularly on varied teaching strategies appropriate to the learners... Fourth, the curriculum should train them on how to use available technology as an essential tool for teaching and learning..." (Participant 06).
\end{abstract}

Societal relevance. Furthermore, the intended teacher education curriculum should have greater relevance to encompass not only the personal and professional levels but also the societal level. The education stakeholders indicated that a teacher education that fulfills societal relevance should inculcate among its prospective teachers the 
peace education, community research, ecological literacy, global citizenship, and multicultural literacy.

The societal dimension of relevance has been suggested by the participants as they attempted to define relevance in the regional context of the teacher education curriculum under study. A participant, drawing from her perspectives as an administrator, expressed that:

"I believe that for the teacher education to be relevant, we need to incorporate also the global citizenship education which provides basic skills on leadership, citizenship, global awareness, so on and so forth, that includes and has something to do with climate change, disaster risk reduction, gender sensitivity, violent extremism, radicalization" (Participant 10).

On the other hand, another participant seemed to justify the societal dimension of relevance that must be considered for the teacher education curriculum. He elaborated that:

"If relevance is neglected in the curriculum, no meaningful learning will take place. Relevance can be incorporated by taking into consideration the current demands of the community. These demands should be emphasized in the course of learning so that, as educators, we can help address the problems of the society" (Participant 04).

\section{DISCUSSION}

Based on the results of the study, relevance in the context of teacher education can be broadly organized into three themes: personal relevance, professional relevance, and societal relevance. As a construct, relevance has been recently investigated in whole or in part particularly across the different fields and aspects of education (e.g. see Cheplogoi, 2016; Dirin \& Nieminen, 2016; Hiim, 2017; Janssen-Brandt et al., 2017; Johnson et al., 2017; Kotkas et al., 2016; Mumbo \& Kinaro, 2015; Mungure, 2016; Pengestu, 2019; Rao \& Wedajo, 2018; Roofe, 2020).

Hartwell (2014) alludes to the works of Dewey (1902) as providing an initial broad outline for what he contended as personal relevance. Thus, in his study, he focused on relevance as personal connectivity which occurs when learners perceive a connection between educational experiences and their lives. Such a depiction of personal relevance is supported by Ranaweera (1990) who describes relevance as the extent to which meets the needs and interests as well as intellectual and physical abilities of the learners.

Moreover, relevance relates to the learners not only personally but also to their profession. Hazarika (1990) in describing a professionally relevant curriculum, states that the curriculum should seriously include employment information and vocational guidance for learners to gain work experience to achieve relevance. Marrin (1993) similarly equates relevance as to how graduates believed that their job was very related to their study. This implies that a curriculum if it should be relevant, has a major role in equipping its learners with professional knowledge, skills, and values to become relevant to their future professions.

On the other hand, for the curriculum to be relevant at the societal level, UNESCO (1990) cited by Ranaweera (1990) says that it should build on the social, historical, and cultural traditions of the country, economic conditions, environment, national development goals, natural endowments and the life of the community. Ranaweera (1990) adds that the social relevance of the curriculum is to train the students in the application of what they learned from the subjects to the practical problems of the community. These practical problems should guide the framework of the school's activities to make education relevant.

Furthermore, it should be noted that such a depiction of relevance has two characteristics. First, relevance is multifaceted. When examining the concepts that consist of each theme, one will find multiple perspectives of relevance. Second, relevance is expanding in nature. The three themes themselves represent an expanding degree of relevance starting from the learner to the society. This model of relevance is depicted in Figure 1.

This model of the criterion of relevance appears to be both similar and disparate to some degree to previous descriptive portrayals of relevance. The earlier definition of UNESCO (2017) about relevance in the context of education states that relevance is the applicability of a curriculum to the needs, interests, aspirations, and expectations of learners and society in general. While two themes appear in this definition - learner and society - so does the present study but further specifying the personal and professional dimension of the learner theme.

This reconstruction is further supported in the seminal study of Robins (1974) on relevance in higher education. The most recurring response from the stakeholders about relevance stated that relevance is the "provision of an educational experience which prepares the individual student for life including a job, meeting the continual changing society, current social problems and issues, and personal problems" (p. 45). This definition, though not structured as the present one, encapsulates the themes of personal relevance, professional relevance, and societal relevance revealed in the present study.

Lastly, Ranaweera (1990) considers relevance in six categorical terms. First, personal relevance; parental occupation, traditional practices, and mother tongue; third, a specific setting whether rural or urban; fourth is temporal relevance such as preparatory education, learning skills, and occupational skills in different life stages; fifth, national relevance whether economic, political, social, cultural or religious context; and lastly is global or universal relevance which includes peace, human values, and global issues. While it diversely structures relevance in numerous categorical terms, nonetheless, it captures the three themes uncovered in this study.

\section{CONCLUSION}

This work primarily aimed to propose a conceptual model of relevance of the teacher education curriculum. Drawing from the different perspectives of education stakeholders, this study depicts relevance through three themes: personal relevance, professional relevance, and societal relevance. It proposes a conceptual model of relevance in the context of teacher education curriculum that is multifaceted and can be presented through three expanding levels.

This study contributes a piece of conceptual evidence as regards the criterion of relevance. Amid the array of definitions of relevance in the different fields and contexts, it specifically offers a glimpse into the field of teacher education and the context of the present study. Furthermore, this research provides a practical guide. As teacher education is continuously pressured to be relevant amid changes, it can be used in the future to assist practitioners in the continuous development of the teacher education intended curriculum. 


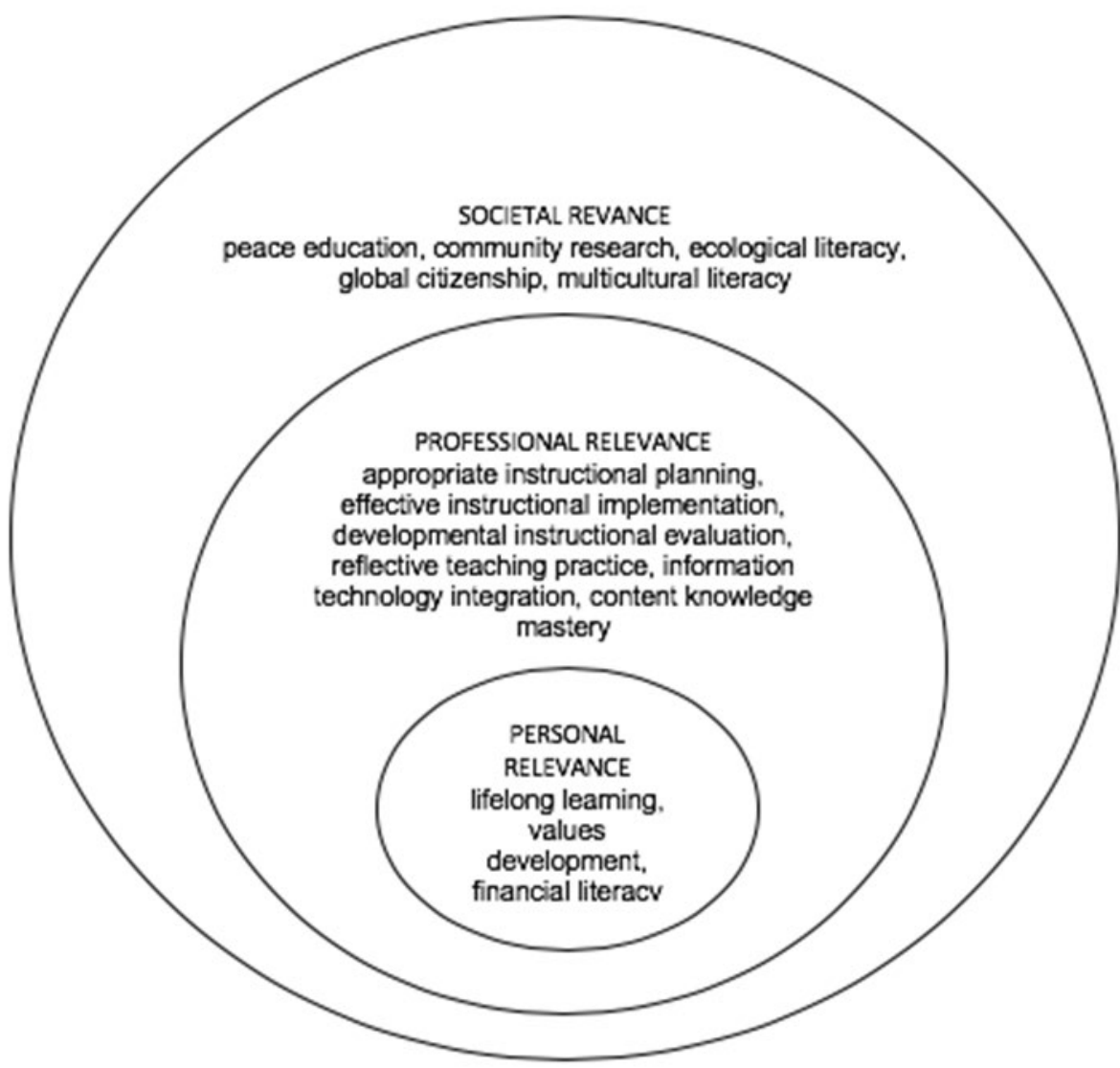

Figure 1. Conceptual model of the relevance of teacher education curriculum

It should be underscored, however, that model development as a research process is rigorous. Thus, it is suggested that the preliminary results of this study should be continuously validated using robust sources and techniques.

Funding: The author received no financial support for the research and/or authorship of this article.

Declaration of interest: Author declares no competing interest.

Data availability: Data generated or analysed during this study are available from the author on request.

\section{REFERENCES}

Carver, F. B. (1990). The relevance of American environmental health curricula in relation to the environmental health education needs of Third World countries (Doctoral dissertation). Available from ProQuest Dissertations and Theses database (UMI No. 9033546).

Chelplongoi, S. K. (2016). Relevance of curriculum in private colleges to the national goals of education: The case of commercial colleges in Baringo County, Kenya. EPRA International Journal of Economic and Business Review, 4(2), 48-55. Retrieved from https://eprawisdom.com/jpanel/upload/articles/

Creswell, J. W. (2013). Qualitative inquiry \& research design: Choosing among five approaches. Thousand Oaks, CA: SAGE.

Curriculum relevance. (2020). Glossary of Curriculum Terminology, International Bureau of Education, United Nations Educational, Scientific and Cultural Organization. Retrieved from http://www.ibe.unesco. org/en/glossary-curriculum-terminology/c/curriculum-relevance
Denzin, N. K., \& Lincoln, Y. S. (2017). The SAGE handbook of qualitative research (5th ed.). Thousand Oaks, CA: SAGE. https://doi.org/10.1108/13522750910948815

Dewey, J. (1902). The child and the curriculum. Chicago: University of Chicago Press.

Dirin, A., \& Nieminen, M. (2016). Relevance of UCD education to software development: Recommendation for curriculum design. Proceedings of the 8th International Conference on Computer Supported Education. https://doi.org/10.5220/0005797901120120

Hartwell, M. (2014). Relevance in the science classroom: a multidimensional analysis (Doctoral dissertation). Available from ProQuest Dissertations and Theses database (UMI No. 3623170).

Hazarika, S. D. (1990). The relevance of curriculum to socio-economic needs: a case study of India (Doctoral dissertation). Available from ProQuest Dissertations and Theses database (UMI No. 041048).

Hiim, H. (2017). Ensuring curriculum relevance in vocational education and training: Epistemological perspectives in a curriculum research project. International Journal for Research in Vocational Education and Training, 4(1), 1-19. https://doi.org/10.13152/ijrvet.4.1.1

Husbands, S., Jowett, S., Barton, P. M., \& Coast, J. (2017). How qualitative methods can be used to inform model development. PharmacoEconomics, 35(6), 607-612. https://doi.org/10.1007/ s40273-017-0499-z 
Janssen-Brandt, X. M. C., Muijtjens, A. M. M., \& Sluijsmans, D. M. A. (2017). Toward a better judgment of item relevance in progress testing. BMC Medical Education, 17(1), 151 https://doi.org/10.1186/s12909-017-0989-x

Kampamba, J., Tembo, E., \& Nkwae, B. (2017). An evaluation of the relevance of real estate curricula in Botswana. Property Management, 35(3), 275-305. https://doi.org/10.1108/pm-12-2015-0065

Kotkas, T., Holbrook, J., \& Rannikmäe, M. (2016). Identifying characteristics of science teaching/learning materials promoting students' intrinsic relevance. Science Education International, 27(2), 194-216. Retrieved from https://files.eric.ed.gov/fulltext/ EJ1104649.pdf

Levitt, K. E. (2002). An analysis of elementary teachers' beliefs regarding the teaching and learning of science. Science Education, 86(1), 1-22. https://doi.org/10.1002/sce.1042

Lewis, R. M. (2002). Mathematics for all? The cultural relevance of connected mathematics (Doctoral dissertation). Available from ProQuest Dissertations and Theses database (UMI No. 1411090).

Lombard, I. (1999). Towards relevance in language teaching: An outcomesbased approach. (Doctoral dissertation). Available from ProQuest Dissertations and Theses database (UMI No. 0666349).

Mahmood, S. (2001). Identifying training needs for teachers in the commercial, technical institutes. Studies in Curricula and Instruction, $70(2), 113-135$.

Marrin, D. M. (2000). A study of the career choice relevance of the undergraduate business education at four private southern California colleges implications to the curriculum. Available from Bell \& Howell Information and Learning Company (UMI Microform 9983695).

Milenski, P. E. (1973). A curriculum development model for the high school English department chairman (Doctoral dissertation). University of Massachusetts, Boston.

Moore, D. S., \& McCabe, G. P. (2005). Introduction to the practice of statistics (5th Ed.). New York: W.H. Freeman \& Company.

Mumbo, H., \& Kinaro, J. (2015). Assessment of quality and relevance of curricula development in health training institutions: a case study of Kenya. Human Resources for Health, 13, 67. https://doi.org/10.1186/s12960-015-0048-9

Mungure, D. M. (2016). An exploration of the relevance of the pedagogy and academic content knowledge that are offered to prospective science and mathematics teachers in Tanzania Teachers' Colleges. Journal of Education and Practice, 7(27), 107-114. Retrieved from https://iiste.org/Journals/
Norman, R. (2018). A model for effective curriculum implementation in accredited private higher education institutions in Botswana (Master's thesis). University of South Africa, Pretoria.

Pangestu, D. (2019). Evaluative study relevance of curriculum development model of elementary school teacher education with elementary school curriculum. Terampil: Jurnal Pendidikan Dan Pembelajaran Dasar, 6(1), 14-22. https://doi.org/10.24042/ terampil.v6i1.3827

Patton, M. Q. (1987). How to use qualitative methods in evaluation Newburry, Park, CA: Sage Publications, Inc.

Ranaweera, M. (1990). Relevance, balance and integration of the content of general education: Achievements, trends and issues: A synthesis. UNESCO Institute for Education.

Rao, N. V., \& Wedajo, A. L. (2018). Reforms in Indian teachers' education curriculum: Examining a two-year B.Ed. curriculum in relation to teachers' competencies and commitments. International Journal of Social Relevance \& Concern, 6(2), 1. https://doi.org/10.26821/ijsrc.6.2.2018.6203

Robins, M. (1974). A Study of Program Relevance in Selected Michigan Colleges and Universities. Michigan State University. Xerox University Microfilms, Ann Arbor, Michigan 48106.

Roofe, C. (2020). Curriculum as place: The social relevance of the secondary school curriculum in Jamaica. The Curriculum Journal. https://doi.org/10.1002/curj.70

Skinner, W. (1978). Student and faculty perceptions of relevance of the secondary curriculum. Arizona State University, University Microfilms International.

Stroupe, W. E. (2003). A study of West Virginia State Police Academy graduates' perceptions of their degrees of competence and the relevance of the Marshall University Community and Technical College police science curriculum (Doctoral dissertation). Marshall University, West Virginia.

Stuckey, M., Hofstein, A., Malmok-Naaman, R., \& Eilks, I. (2013). The meaning of 'relevance' in science education and its implications for the science curriculum. Studies in Science Education, 49(1), 1-34. https://doi.org/10.1080/03057267.2013.802463

Wallace, D. K. (1999). Curriculum development in professional education: a design model for information studies (Doctoral dissertation). University of Toronto, Canada. 